\title{
Language in Children with Neonatal Hypoxic-Ischemic Encephalopathy
}

\author{
Chenia Martinez $^{1}$ Luciana Carneiro ${ }^{1} \quad$ Luíza Vernier $^{1}$ \\ ${ }^{1}$ Departamento de Fonoaudiologia, Universidade Federal de Ciências \\ da Saúde de Porto Alegre, Porto Alegre, RS, Brazil \\ 2 Faculdade Nossa Senhora de Fátima, Caxias do Sul, RS, Brazil \\ ${ }^{3}$ Departamento de Neurologia, Universidade Federal de Ciências da \\ Saúde de Porto Alegre, Porto Alegre, RS, Brazil \\ ${ }^{4}$ Departamento da Pró-reitoria de Extensão de Assuntos \\ Comunitários, Universidade Federal de Ciências da Saúde de Porto \\ Alegre, Porto Alegre, RS, Brazil
}

Int Arch Otorhinolaryngol 2014;18:255-259.

\section{Carla Cesa ${ }^{2}$ Ana Guardiola ${ }^{3}$ Deisi Vidor ${ }^{4}$}

\begin{abstract}
Address for correspondence Chenia Martinez, Departamento de Fonoaudiologia, Universidade Federal de Ciências da Saúde de Porto Alegre, Rua Sarmento Leite, 245 Porto Alegre, Rio Grande do Sul 90050170, Brazil (e-mail: chenia.martinez@gmail.com).
\end{abstract}

\begin{abstract}
Keywords

- language development

- hypoxia

- brain

- brain ischemia

- neurology

- speech

- language

- and hearing sciences

Introduction Neonatal hypoxic-ischemic encephalopathy (NHIE) is a common neurologic injury, and it may compromise the child's language and cognition. Understanding the process of language acquisition becomes possible with concise knowledge about children's global development.

Objective The aim of this study was to observe if language acquisition and development are impaired in children with NHIE.

Methods Seventy children with NHIE from 1 to 24 months old were analyzed in a Pediatric Neurology Service of Hospital of Porto Alegre, South of Brazil using the BrunetLezine Scale. Statistical analysis used SPSS 13.0 software.

Results Twenty-four (60\%) of the subjects were boys, with mean gestational age of 35.8 weeks (standard deviation of 4.6) and mean Apgar score of 6.0 at 1 minute and 7.1 at 5 minutes. The variables age versus language showed significant inverse correlation ( $r=-0.566 ; p=0.028)$. As the subjects aged, language tasks became more specific and dependent on the subject's direct action, rather than the subjective interpretation of their guardian. This correlation seems to be closely associated with scale configuration and with consequences of neurologic disorder, evincing the delays in language development. Conclusion This study achieved the goals proposed and highlights the necessity of greater attention by professionals to language skills during the initial period of child development.
\end{abstract}

\section{Introduction}

Neonatal hypoxic-ischemic encephalopathy (NHIE) is a neurologic disorder that can cause disturbances in global development of children. ${ }^{1,2}$ It is the most prevalent neurologic disorder in the neonatal period, and the deleterious effects of hypoxia and ischemia can affect the central nervous system of newborns. ${ }^{1,3,4}$ This neurologic disorder occurs in $~ 33 \%$ of newborns with neonatal asphyxia. ${ }^{5}$

received

October 9, 2013

accepted

December 8, 2013

published online

February 10, 2014
DOI http://dx.doi.org/ 10.1055/s-0034-1366976. ISSN $1809-9777$.
Language is a communication device that involves the use of verbal and nonverbal symbols. Language, in relation to the evolution of overall process of communication, is closely related to global development aspects, such as cognition and social skills. ${ }^{6-8}$ In relation to language disorders, some factors are frequently associated: inadequate environmental stimulus, particular and individual rhythm of global development, emotional conditions, social maturity, hereditary factors, diseases, and sequelae before,
Copyright $\odot 2014$ by Thieme Publicações License terms Ltda, Rio de Janeiro, Brazil

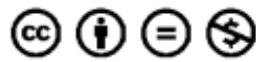


during, and after birth affecting the neurologic system and other complications. ${ }^{1,6,8,9}$

Absence of language within expected chronological limits or a slow and difficult acquisition process can indicate global development disorders of children. One parameter to characterize language delay is related to the child's age. No language acquisition by about 2 years old can mean difficulties of language development. ${ }^{6,10,11}$ A study showed that a difference of at least 12 months between the linguistic age and chronological age of children may indicate difficulties in language acquisition and development. ${ }^{12}$

Language skills of children can be perceived and understood even before its oral manifestations, based on some underlying mechanisms to normal language development. The analysis of communication in this period includes the observation of prelinguistic, cognitive, and social development. ${ }^{6,13}$ Studies have been conducted with the aim of development of tests for early identification of children at high risk for development disorders. ${ }^{14-16}$ This early detection and intervention of cognitive, linguistic, and social disorders is essential to prevent and minimize losses. ${ }^{10,16}$

This study intends to demonstrate the necessity that language be investigated in young children, because in the early period of child development, language is expressed, principally, by prelinguistic manifestations. $^{8}$

The literature presents several studies relating language and neonatal intercurrences but still has few studies that relate newborn linguistic aspects and Brazilian children with NHIE, especially in early period of development. The aim of this study was observe if children with NHIE have language acquisition and development disorders.

\section{Methods}

Research data obtained from a large cross-sectional field study were collected individually in an Ambulatory of High Brain Function of the Pediatric Neurology Service in a children's hospital for advanced treatment, located in the city of Porto Alegre, Rio Grande do Sul, Brazil, over 2 years. All participants' parents or caregivers signed the informed consent, according to the source institution Ethics in Research Committee approval of the $607 / 10$ project number.

The study sample was composed of 70 children diagnosed with NHIE. These subjects were referred by a pediatric neurologist at the moment of discharge from a neonatal intensive care unit, where the newborns were admitted due to the neonatal neurologic complications that caused brain hypoxia or ischemia. The patient follow-up initially consisted of anamnesis, medical consultation, and assessment of global neurodevelopment measured by the BrunetLezine Scale (Psychomotor Development in Early Infancy). ${ }^{17}$ This test was administered by a pediatric neurologist.

The Brunet-Lezine Scale assesses children up to 6 years old. It has the aim of measuring the global neurodevelopment, observing the following main areas: posture and gross motor adaptation, fine motor skills, language skills, and social skills. The scale developed by Brunet and Lezine was translated to Portuguese and adapted to Brazil; although it has been internationally validated, it has not been validated in a Brazilian population. This scale was adopted for this study because it was a routinely used with all patients in this ambulatory setting and because the scale exposes good clinical results in NHIE patients' follow-up.

The scale was used until patients were 24 months old, totaling 15 tests (monthly between 1 to 10 months and then at $12,15,18,21$, and 24 months). Each level is composed of 10 items ( 6 tests observed in the neurologic examination and 4 questions directed to the caregivers).

Because patients were seen regularly according to the specific necessity of each case, data were tabulated monthly, according to the number of patients assessed at that specific age. It is important to highlight that the age considered in this examination is the corrected age of patient. Data were analyzed and verified by the Pearson correlation coefficient $(r)$ and Fisher exact test, using the descriptive statistics. The maximum $\alpha$ level accepted was 5\% $(p \leq 0.05)$ and the SPSS 13.0, Inc. product, from Chicago, IL, USA, was used for statiscal analysis.

\section{Results}

Characterization data of this study sample were obtained by the pediatric neurologist in the first consultation ( - Table 1 ). Thirty-eight (54.28\%) of the subjects had gestational age less than 37 weeks, considered as preterm according to the literature. $^{18}$

The studied sample obtained mean results of $84.63 \%$ in the language domain, $86.50 \%$ in social skills, $73.38 \%$ in psychomotor performance, and $74.35 \%$ in posture. These domains were also correlated to language. - Table 2 reveals the results of Pearson correlation test, which found no statistical significance among the variables with respect to the language domain.

Using the data, the executed tasks in the language domain and the sex of participants were compared (-Table 3 ). Fischer exact test verified that the language variable was not significantly related to the sex of children, although it visually demonstrated a trend toward better performance in girls.

It was further investigated whether linguistic performance paralleled the growth and the neurodevelopment of participants by crossing the variables of percentage of children who performed the language domain tasks versus age in months. Pearson correlation analysis found the higher the age of

Table 1 Characterization data of sample

\begin{tabular}{|l|l|l|l|}
\hline Variable & $\boldsymbol{n}$ & $\%$ & Average \pm SD \\
\hline Sex & 42 & 60 & - \\
Male & 28 & 40 & - \\
Female & & & \\
\hline Gestational age & 70 & - & $35.8 \pm 4.6$ \\
\hline Apgar 1min & 70 & - & $6.0 \pm 2.3$ \\
\hline Apgar 5min & 70 & - & $7.1 \pm 2.0$ \\
\hline
\end{tabular}

Abbreviation: SD, standard deviation. 
Table 2 Results of correlation analysis with variable percentage of children who performed tasks of domain language

\begin{tabular}{|l|l|c|}
\hline \multirow{2}{*}{ Variable } & \multicolumn{2}{|l|}{ Correlation to language } \\
\cline { 2 - 3 } & Pearson $\boldsymbol{r}$ & $\boldsymbol{p}$ \\
\hline Posture & 0.009 & 0.974 \\
\hline Psychomotor performance & 0.214 & 0.445 \\
\hline Social skills & 0.236 & 0.398 \\
\hline
\end{tabular}

children, the lower the percentage of executed tasks in the language domain $(r=-0.566 ; p=0.028)$.

-Fig. 1, a dispersion diagram, shows the percentage of children who performed the language domain tasks by age (in months). A negative dispersion was observed.

\section{Discussion}

The prevalence of prematurity is highlighted in this sample. This can affect neurodevelopment, ${ }^{19-22}$ increasing the risk of morbidity, mortality, and prolonged hospitalization ${ }^{23}$ and interfering with brain maturation processes. It can lead to structural and anatomical disorders, occasionally resulting in functional, cognitive, and behavioral disabilities. ${ }^{21}$ The

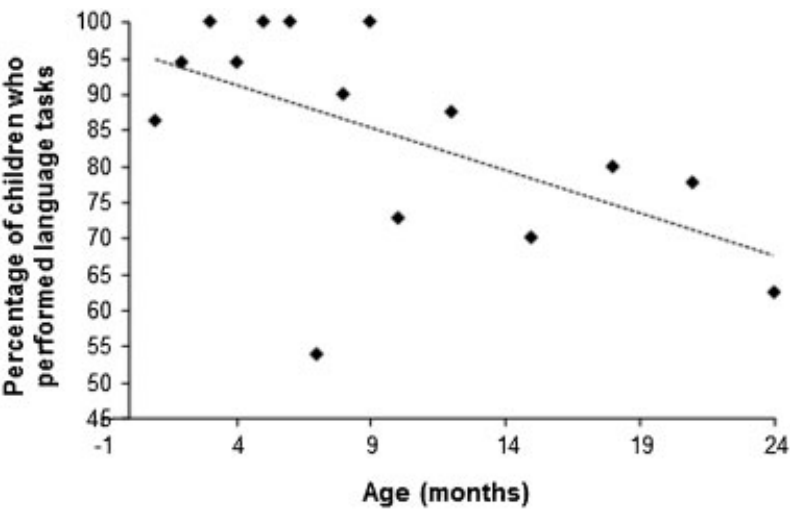

Fig. 1 Variable dispersion: percentage of children who performed the language domain tasks versus age in months.

literature also notes that children hospitalized for long periods are often deprived of environmental stimulation and maternal contact. ${ }^{19}$ However, there are no studies in the Brazilian literature about the relation between delay in language acquisition in children with NHIE. In this context, it is believed that the delay in language acquisition may be influenced by these factors.

A meta-analysis demonstrated that premature infants have significantly lower scores on functional language tests

Table 3 Comparison between male and female in executed language tasks

\begin{tabular}{|c|c|c|c|c|c|c|c|c|}
\hline \multirow[t]{3}{*}{ Task } & & \multicolumn{6}{|c|}{ Sex } & \multirow[t]{3}{*}{$p^{a}$} \\
\hline & \multirow[b]{2}{*}{ Month } & \multicolumn{3}{|c|}{ Male } & \multicolumn{3}{|c|}{ Female } & \\
\hline & & $n$ & Done & $\%$ & $n$ & Done & $\%$ & \\
\hline Produces guttural sounds & 1 & 12 & 10 & 83.3 & 10 & 9 & 90.0 & 0.571 \\
\hline Produces some vocalizations & 2 & 10 & 10 & 100.0 & 8 & 7 & 87.5 & 0.444 \\
\hline Chatter: prolonged vocalizations & 3 & 7 & 7 & 100.0 & 3 & 3 & 100.0 & - \\
\hline Vocalizes when spoken to & 4 & 12 & 12 & 100.0 & 6 & 5 & 83.3 & 0.333 \\
\hline Shouts in happiness & 5 & 2 & 2 & 100.0 & 6 & 6 & 100.0 & - \\
\hline Babbles & 6 & 8 & 8 & 100.0 & 6 & 6 & 100.0 & - \\
\hline Vocalizes several well-defined syllables & 7 & 7 & 5 & 71.4 & 6 & 2 & 33.3 & 0.209 \\
\hline Participates in game of hide and seek & 8 & 3 & 2 & 66.7 & 7 & 7 & 100.0 & 0.300 \\
\hline Speaks a word of two syllables & 9 & 2 & 2 & 100.0 & 2 & 2 & 100.0 & - \\
\hline Repeat a heard sound & 10 & 5 & 3 & 60.0 & 6 & 5 & 83.3 & 0.404 \\
\hline Speaks three words & 12 & 12 & 10 & 83.3 & 4 & 4 & 100.0 & 0.550 \\
\hline Speaks five words & 15 & 8 & 5 & 62.5 & 2 & 2 & 100.0 & - \\
\hline Recognizes a image or shows two images & 18 & 3 & 2 & 66.7 & 2 & 2 & 100.0 & - \\
\hline Recognizes five body parts of doll & 21 & 2 & 1 & 50.0 & 1 & 1 & 100.0 & - \\
\hline Associates two words & 21 & 2 & 1 & 50.0 & 1 & 1 & 100.0 & - \\
\hline Asks to feed and drink & 21 & 2 & 2 & 100.0 & 1 & 1 & 100.0 & - \\
\hline Nominates two images or shows four images & 24 & 5 & 1 & 20.0 & 3 & 2 & 66.7 & - \\
\hline Produces sentences of several words & 24 & 5 & 3 & 60.0 & 3 & 3 & 100.0 & - \\
\hline Nominates his- or herself by the first name & 24 & 5 & 3 & 60.0 & 3 & 3 & 100.0 & - \\
\hline
\end{tabular}

${ }^{\text {a}}$ Fisher exact test. 
compared with children born at term, and these difficulties tend to persist throughout the child's development until early adolescence. $^{24}$ This study lacks the nonsubjective language measurement, because the study covers structural and instrumental aspects. The present study showed a high index of correct executions in language domains. This finding contradicts one study, ${ }^{24}$ which showed significantly lower scores in functional language tests in preterm subjects. However, there is no denying the influence of prematurity on child development when combined with NHIE. It can increase the negative impact of this intercurrence in the acquisition and development of language.

The Apgar score is an important instrument of neonatal assessment that includes five components: heart rate, respiratory effort, muscle tone, reflex irritability, and color. Each aspect is scored 0,1 , or 2 and is assessed at 1 and 5 minutes after birth. According to the American Academy of Pediatrics and the American College of Obstetricians and Gynecologists, ${ }^{25}$ an Apgar score of 7 to 10 is considered normal, and to determine risk factors to neurologic disorders, it is necessary to relate this score with other health complications. ${ }^{26}$ These study data do not support the current literature, which describes that Apgar score below 7 can be associated with NHIE. ${ }^{27}$ The most significant data come from larger samples.

A better performance was seen in girls, showing that boys are frequently more affected in language disorders. ${ }^{28,29}$ In the present study, no task was significantly related to this variable. However, it is important to observe that until 10 months, with exception of language task at 7 months (vocalizing several well-defined syllables), in which boys showed better performance in relation to girls, the performance of both sexes was quite similar. From this period, the performance of girls was clearly better than boys in this domain; - Table 3 presents the list of language tasks.

Researchers have suggested that organic, structural, and hormonal disorders may be the cause of this difference between gender. ${ }^{28,30}$ It is also highlighted that the interference of differentiated attitude by adults in relation to boys' and girls' language acquisition is an environmental factor that can contribute to this difference. ${ }^{31}$ It is believed that statistically significant differences in languages tests between boys and girls should appear in longitudinal studies; with increasing age, it is possible to observe the environmental interferences with more evidence.

As shown in - Fig. 1, by the Pearson correlation, with increasing age, children start to present worse performance in language tests. This finding corroborates a study that assesses psychomotor development by Brunet-Lezine Scale. In this study, the development quotients in each area tended to decrease during the consultations, ${ }^{32}$ revealing a progressively unsatisfactory development throughout the period.

\section{Conclusion}

The present study found statistical significance in relation to participants' language and age, indicating that children with NHIE tended to have delayed language skills, with more evidence shown with advancing age. In this context, the observation of the findings related to the language of children with NHIE indicates that deficits may become evident only with advancing age and stages of child neurodevelopment.

No relation between participants' language and sex was observed, although a trend toward better performance on language tasks by girls was noted. Also, it is necessary to validate the Brunet-Lezine Scale in Brazil, to standardize and provide greater reliability in the findings. In this context, disorder traces can be early identified, favoring diagnosis and interventions in children's early neurodevelopment. More scientific research is necessary in this area, with larger samples, to better understand the various processes related to language acquisition and development in these patients.

This study reinforces the importance of observing infant manifestations and intensifying investigations on this topic, seeking precise understanding of the processes involved. The essential function of the speech therapist allied with the hospital team is highlighted, following these patients from birth through adolescence.

\section{References}

1 Diament A, Cypel S. Neurologia infantil. 4ª ed. Vol. 2. São Paulo Brazil: Atheneu; 2005

2 Wyatt JS, Gluckman PD, Liu PY, et al; CoolCap Study Group. Determinants of outcomes after head cooling for neonatal encephalopathy. Pediatrics 2007;119(5):912-921

3 Corrêa RRM, Salge AKM, Ribeiro GA. Anatomic and pathological placenta alterations and Apgar score variations. Rev Bras Saude Mater Infant 2006;6(2):239-243

4 Cruz ACS, Ceccon MEJ. Prevalence of asphyxia and perinatal hypoxic-ischemic encephalopathy in term newborns, considering two diagnostic criteria. Rev Bras Crescimento Desenvolv Hum 2010;20(2):302-316

5 Volpe JJ. Neurology of the Newborn. 4th ed. Philadelphia PA: W.B. Saunders; 2001:217-394

6 Zorzi JL. A intervenção fonoaudiológica nas alterações da linguagem infantil. 2 ed. Rio de Janeiro Brazil: Revinter; 2002

7 Oliveira JP, et al. Communicative profile of children who entered in primary school after the age of five. Rev Bras Promoc Saude (Impr.) 2010;23(2):160-167

8 Amorim R. Avaliação da criança com alteração da linguagem. Nascer e Crescer 2011;20(3):174-176

9 Scopel RR, Souza VC, Lemos SMA. A influência do ambiente familiar e escolar na aquisição e no desenvolvimento da linguagem: revisão de literatura. Rev CEFAC. 2012;14(4):732-741. Available at: http://dx. doi.org/10.1590/S1516-18462011005000139. Accessed in Sep 18, 2013

10 Zorzi JL. Aspectos básicos para compreensão, diagnóstico e prevenção dos distârbios de linguagem na infância. Rev CEFAC 2000;2(1):11-15

11 Dale PS, Patterson JL. Identificação precoce de atrasos de linguagem. In: Tremblay RE, Boivin M, Peters RDV, eds. Enciclopédia sobre o Desenvolvimento da Primeira Infância. Montreal QuebecCentre of Excellence for Early Childhood Development2011:1-6. Available at: http://www.enciclopedia-crianca.com/documents/ Dale-PattersonPRTxp1-Linguagem.pdf. Accessed in July 8, 2013

12 Befi-Lopes DM, Gândara JP, Felisbino FS. Categorização semântica e aquisição lexical: desempenho de crianças com alteração do desenvolvimento da linguagem. Rev CEFAC 2006;8(2):155-161

13 Pedroso FS, Rotta NT, Danesi MC, Ávila LN, Sávio CB. Evolução das manifestções pré-linguísticas em crianças normais no primeiro ano de vida. Rev Soc Bras Fonoaudiol. 2009;14(1):22-25

14 Lee LL, Harris SR. Psychometric properties and standardization samples of four screening tests for infants and young children: a review. Pediatr Phys Ther 2005;17(2):140-147 
15 Santos RS, Araujo APQC, Porto MAS. Diagnóstico precoce de anormalidades no desenvolvimento em prematuros: instrumentos de avaliação. J Pediatr 2008;84(4):289-299

$16 \mathrm{Kim}$ SW, Han ZA, Jeon HR, et al. Neurodevelopmental disorders of children screened by the infantile health promotion system. Ann Rehabil Med 2011;35(6):867-872

17 Brunet O, Lézine I. Desenvolvimento psicológico da primeira infância. Tradução de Ana Guardiola Brizolara. Porto Alegre, Brazil: Artes Médicas; 1981

18 Egewarth C, Pires FDA, Guardiola A. Avaliação da idade gestacional de recém nascidos pré-termo através do exame neurológico e das escalas neonatais e obstétrica. Arq Neuropsiquiatr 2002;60(3-B):755-759

19 Ayache MG, Mariani Neto C. Considerations on the motor development of the premature. Temas Desenvolv 2003;12(7):5-9

20 Oliveira LN, Lima MCMP, Gonçalves VMG. Acompanhamento de lactentes com baixo peso ao nascimento: aquisição da linguagem. Arq Neuropsiquiatr 2003;61(3B):802-807

21 Zomignani AP, Zambelli HJL, Antônio MARGM. Cerebral development in preterm newborn infants. Rev Paul Pediatr. 2009;27(2): 63-67

22 Rocha SR, Dornelas LF, Magalhães LC. Assessment tools utilized for the evaluation of preterm neonates in Brazil: literature review. Cad Ter Ocup UFSCar 2013;21(1):109-117

23 Escobar GJ, Mccormick MC, Zupancic JA, et al. Unstudied infants: outcomes of moderately premature infants in the neonatal intensive care unit. Arch Dis Child Fetal Neonatal Ed 2006;91(4):F238-244

24 van Noort-van der Spek IL, Franken MC, Weisglas-Kuperus N. Language functions in preterm-born children: a systematic review and meta-analysis. Pediatrics 2012;129(4):745-754
25 American Academy of Pediatrics, Committee on Fetus and Newborn American College of Obstetricians and Gynecologists, Committee on Obstetric Practice. The Apgar score. Pediatrics 2006; 117:1444-7. Available at: www.pediatrics.org/cgi/doi/10.1542/ peds.2006-0325. Accessed in Aug 23, 2013

26 American College of Obstetrics and Gynecology, Task Force on Neonatal Encephalopathy and Cerebral Palsy. American Academy of Pediatrics. Neonatal Encephalopathy and Cerebral Palsy: Defining the Pathogenesis and Pathophysiology. Washington, DC: American College of Obstetricians and Gynecologists; 2003

27 Salustiano EMA, Campos JA, Ibidi SM, Ruano R, Zugaib M. Low Apgar scores at 5 minutes in a low risk population: maternal and obstetrical factors and postnatal outcome. Rev Assoc Med Bras 2012;58(5):587-593

28 Kandel ER, Schamartz JH, Jessel TM. Principles of Neuroscience. New York, NY: McGraw-Hill; 2000

29 Vidor DCGM. Aquisição lexical inicial por crianças falantes de português brasileiro: discussão do fenômeno da explosão do vocabulário e da atuação da hipótese do viés nominal [Tese Doutorado em Letras]. Instituto de Letras e Artes da PUCRS, Porto Alegre, Brasil; 2008

30 Johnston MV, Hagberg H. Sex and the pathogenesis of cerebral palsy. Dev Med Child Neurol 2007;49(1):74-78

31 Kovas Y, Hayiou-Thomas ME, Oliver B, Dale PS, Bishop DV, Plomin R. Genetic influences in different aspects of language development: the etiology of language skills in 4.5-year-old twins. Child Dev 2005;76(3):632-651

32 Bee HL, Mitchell SK, Barnard KE, Eyres SJ, Hammond MA. Predicting intellectual outcomes: Sex differences in response to early environmental stimulation. Sex Roles 1984;10(9-10):783-803 